\title{
Gyermekes családok és a velük dolgozó szociális szakemberek percepciója a családok jól-létét, társadalmi mobilitását előmozdító szolgáltatásokról
}

\author{
RÁCZ ANDREA ${ }^{1,2}$ - SIK DOROTTYA ${ }^{3}$
}

\begin{abstract}
ABSZTRAKT
Tanulmányunkban azt vizsgáljuk, hogy az észak-magyarországi régió egyik hátrányos helyzetü kistérségében különböző településnagyságú területeken, illetve a budapesti agglomerációhoz tartozó településeken élő gyermekes családok hogyan vélekednek az elérhető oktatási, gyermeknevelési, egészségügyi és szociális ellátásokról és szolgáltatásokról, ezekről egyáltalán rendelkeznek-e információval, valamint a gyermekes családokkal dolgozó szakemberek mit gondolnak a nyújtott szolgáltatás szakmai tartalmáról és minőségérôl, valamint arról, hogy ezek a családok jól-létét, társadalmi mobilitási esélyeit mennyiben tudják szolgálni. Kutatásunk keretében készült egy lakossági kérdöíves lekérdezés, valamint interjúk készültek szakemberekkel és gyermekes családokkal. Eredményeink jelzik, hogy a gyermekek képességeit fejlesztő, tehetségük kibontakozását célzó, jól-létüket előmozdító szolgáltatások hiányában, a meglévő, igen korlátozott kapacitásokkal és így alacsony minőségben müködő oktatási, egészségügyi, szociális szolgáltatások és a szükösen elérhető kulturális és szabadidős lehetőségek elérésével a hátrányos helyzetű családokban felnövő gyermekek mobilitási esélyei nagymértékben korlátozottak. A gyermekjóléti szociális munka eszköztára szükös, a szociális intervenciók a tüzoltásra épülnek.
\end{abstract}

KULCSSZAVAK: sZociális munka, gyermekjóléti szolgáltatás, társadalmi mobilitás, gyermekes családok segítése

\footnotetext{
${ }^{1}$ Rácz Andrea, ELTE TáTK Szociális Munka Tanszék, e-mail: racz.andrea.aniko@tatk.elte.hu

${ }^{2}$ A tanulmány megírását a 'Mobilitás és immobilitás a magyar társadalomban' c. MTA Kiválósági Együttműködési Program Mobilitás Kutatási Centrum projektje támogatta, valamint az MTA Bolyai János Kutatási Ösztöndíj, az Információs és Technológiai Minisztérium ÚNKP-19-4 kódszámú Új Nemzeti Kiválóság Programja, valamint Szolidaritás a késő modernitásban c. OTKA kutatás (Sik Domonkos FK 129138). A kutatás az ELTE TáTK Szociális Munka Tanszékén valósult meg Szociális és gyermekvédelmi ellátórendszer működési mechanizmusai címmel.

${ }^{3}$ Sik Dorottya, ELTE TáTK Szociális Munka Tanszék, e-mail: sik.dorottya.borbala@tatk.elte.hu
} 


\section{TEMATIKUS TANULMÁNYOK - Társadalmi mobilitás és segítői tevékenység}

\section{ABSTRACT}

\section{The perception of the families and the concerned social workers} about the promotion of the well-being of the families and social mobility

In the study our goal is to analyse the perception of the families and concerned social workers. The research was established in two regions in Hungary: in an underprivileged and disadvantaged micro-region in North Hungary and in the agglomeration around Budapest. The main focus was the perception of the available educational, social, child welfare and health services and supports. The starting point was their knowledge about these services. Beside the perception of the families, the opinion of the experts in the social support system about the value and quality level of their work is important. Analysing the quality of these services and supports is crucial to understand the mobility chance of the children living in these micro-regions. In our research public questionnaire and interviews with the families and experts were completed. The results show, that without capability and talent development for the children and the lack of welfare services, the mobility chance and opportunity of this families are extremely low. With the current social, education and health care system, and the lack of cultural possibilities, these children stuck in their disadvantaged circumstances without the hope or chance for better opportunities. The social interventions in the current child welfare system is only enough for damage control and not for prevention or increasing equality.

KEYWORDS: social work, child welfare services, social mobility, support for families with children

\section{Bevezetés}

A Szociális munka globális definíciója (2014) értelmében a szociális munka célja a társadalmi változás előmozdítása a nagyobb jó-lét érdekében, így a szociális munka típusú beavatkozásra akkor van szükség, amikor egy adott helyzetben elkerülhetetlen a fejlődés irányába való elmozdulás az egyén, család, csoport és közösség szintjén. „Mozgatórugója azon strukturális feltételek lebontásának és megváltoztatásának az igénye, melyek hozzájárulnak a marginalizációhoz, a társadalmi kirekesztéshez és az elnyomáshoz." (A szociális munka globális definíciója 2014: 97) Tanulmányunkban éppen ezért a szociális munka érték- és célrendszeréből indulunk ki, és azt vizsgáljuk, hogy a kutatás helyszínéül szolgáló észak-magyarországi régió egyik hátrányos helyzetű kistérségében különböző településnagyságú területeken, illetve a budapesti agglomerációhoz tartozó településeken élő gyermekes családok hogyan vélekednek az elérhető ellátásokról és szolgáltatásokról, ezekről egyáltalán rendelkeznek-e információval, valamint a gyermekes családokkal dolgozó szakemberek mit gondolnak a nyújtott szolgáltatás szakmai tartalmáról és minőségéről, valamint arról, hogy ezek a családok jól-létét, társadalmi mobilitási esélyeit mennyiben tudják szolgálni. Elsőként 12 szakemberrel készült interjú alapján a szakemberek álláspontját ismerjük meg, majd a két vizsgálati helyszínen készült lakossági kérdőíves felmérés főbb eredményeit mutatjuk be, illetve az ehhez szorosan kapcsolódó lakossági rövid interjúkban (102 db) megfogalmazott vélekedéseket. Eredményeink jel- 


\section{TEMATIKUS TANULMÁNYOK - Társadalmi mobilitás és segítői tevékenység}

zik, hogy a gyermekek jól-létének, sikeres jövőjének a kulcsa a szocializációjuk során számukra hozzáférhető jóléti szolgáltatásoktól, azok minőségétől és az előttük megnyíló lehetőségektől nagyban függ. A megfelelő szociális és gyermekjóléti ellátórendszer, a jó színvonalú oktatási és egészségügyi szolgáltatások megléte mellett a gyermekeknek egyenlő esélyük lenne a társadalmi mobilitásra, a tehetségüknek és tudásuknak legmegfelelőbb társadalmi pozíció elérésére, illetve arra, hogy kiteljesedjenek abban a szakmában, ami a számukra a lehető legoptimálisabb. Ezen ideális állapottól eltérően ma Magyarországon a gyermekjóléti szolgáltatások által nyújtott támogatások korlátozottsága okán nem biztosítottak a hátránykompenzáló lehetőségek, így a mobilitási csatornák beszűkültek. A szakemberekkel és családokkal készült interjúk tanúsága szerint a lakóhely, a szülők munkaerőpiaci státusza, iskolai végzettsége, a családok anyagi helyzete mellett a lokálisan elérhető szolgáltatások nagyban korlátozzák a gyermekek és családok mobilitási lehetőségeit.

\section{Gyermekjólét és társadalmi mobilitás}

Vajda (2000) szerint a XX. század társadalmi-gazdasági-kulturális változásai elválasztották egymástól a gyermek- és felnőttkort. A XXI. század a későmodernitás világa, ahol a fejlett világban a gyermekek száma csökken, az iskolai problémák, a gyermekszegénység és a gyermeki speciális szükségletek nőnek, komoly kihívás elé állítja a társadalmakat és megkérdőjelezi a XX. században kialakult gyermekkorral kapcsolatos eszményeket (Vajda 2000). A gyermekkor változása, a gyermekekre irányuló jogok kialakulása, a gyermeki szükségletek észlelése és erre való reagálás igénye a gyermekekkel foglalkozó segítő hálózat széles körű kialakulását hozta magával. A gyermekvédelem területén a szolgáltatások, segítségnyújtási formák kiépülése és megvalósítása terén a gyermekek védelmének biztosítása, egyéni szükségleteinek kielégítése a cél. Amikor a gyermekkorról mint társadalmi konstrukcióról gondolkodunk, a gyermekkorról alkotott kép gyakran együtt jár a szegénységgel, kirekesztettséggel, bántalmazással és elhanyagolással. A gyermekek védelme, a gyermeki jól-lét szorosan összefügg a társadalmi mobilitás kérdésével. Ha a társadalomban a mobilitási lehetőségek, mobilitási utak nyitottak a társadalom tagjai számára, különös tekintettel a gyermekekre, azok lehetőségeire, úgy a gyermekvédelem prevenciós szemlélete, a családokat rendszerben kezelő gyermekjóléti rendszer pozitív irányú változásokat képes hozni a családok és a gyermekek életében. Az esetleges hátrányok megfelelő beavatkozásokkal történő csökkentése, a különböző társadalmi egyenlőtlenségek mérséklését célzó intézkedések - összhangban a gyermekvédelem alapvető céljaival és prevenciós szemléletével - a társadalmi integráció és mobilitás szempontjából is különösen fontosak (Stryker et al. 2019). A kirekesztettség, a mobilitási lehetőségek beszűkülése egy folyamat eredménye: az érintett családok és háztartások több fontos társadalmi dimenzióban, mint iskolázottság, munka- 


\section{TEMATIKUS TANULMÁNYOK - Társadalmi mobilitás és segítői tevékenység}

erőpiaci helyzet, lakóhely, lakhatási körülmények, kulturális javakhoz való hozzáférés stb. meglévő hátrányaikat átörökítik a következő generációkra (Messing - Molnár 2011a). Az átöröklődő depriváció, szegénység és kirekesztettség hatását ellensúlyozni olyan társadalmi kapcsolatokkal lehet, amelyek átívelnek a kirekesztett közösségek és hidat képeznek az egyén és a különböző társadalmi szervezetek, állami intézmények között. Ha nincsenek ilyen formális és informális kapcsolatok az egészségügy, oktatás, munkaerőpiac stb. területén, akkor elkerülhetetlen a társadalmi mobilitás ellehetetlenülése, és a kirekesztett társadalmi csoportok további leszakadása (Messing - Molnár 2011b). A társadalmi mobilitás esélyei csak azok számára válnak lehetővé, akik hozzáférhetnek a nem szegregált, jó minőségű oktatáshoz, és rendelkeznek a többségi, nem szegény, nem roma társadalomhoz kötő hídszerű kapcsolatokkal (Váradi 2015). Az OECD (2009) kutatásai alapján az oktatási és munkaerőpiaci hatások határozzák meg leginkább a mobilitási csatornák hatékonyságát. Az OECD (2018) jelentése is alátámasztja, hogy a gyermekek esélyei és a családok mobilitási lehetősége szorosan összefüggenek családjuk szocioökonómai státuszával és a rendelkezésre álló szociális és gyermekjóléti szolgáltatások minőségével.

Fontos röviden szót ejtenünk a hazai gyermekvédelem helyzetéről is ebben a kontextusban. A rendszerváltást követően az 1993-as szociális törvény is foglalkozott a gyermekek védelmével, de nem önmagában nézte a gyermeket, hanem a család részeként. „A törvény, mely a rászorultak támogatása, a szociális segítségnyújtás és a szociális munka társadalmi szervezettsége szempontjából alapvető és egyértelmüen pozitív változásokat hozott." (Czirják 2008: 31) A gyermek családon belüli speciális helyzete az 1997-es Gyermekvédelmi törvénnyel került a fókuszba, mely törvény a gyermekjóléti és gyermekvédelmi struktúrát is kialakította. A gyermekvédelmi törvény szemléletének a lényege a család többirányú támogatása és a klienscentrikusság területi munkába való beépítése (Czirják 2008). Alapvető fontosságú, hogy a hatósági gyermekvédelmet megelőzze az ellátások önkéntes igénybevétele. A korai kutatások is a rendszer hiányosságaira hívták fel a figyelmet, az 1990-es évek végén sok helyen előfordult, hogy önálló helyisége sem volt a gyermekjóléti szolgálatnak és közel 60\%-ban egyszemélyesek voltak a szolgálatok, amely a minőségi szakmai feladatellátást igen bekorlátozta, nem beszélve a hiányos tárgyi feltételekről. Jellemző volt az is, hogy a szolgálatok sokszor kényszermegoldásokat alkalmazva működtek: védőnőket, pedagógusokat, családsegítő szakembereket foglalkoztattak, akik mellékállásként végezték a gyermekjóléti feladatok ellátását (Papp 2000). És bár a célok jól artikuláltak voltak, hiszen a törvény hangsúlyt fektet a prevencióra és ennek megfelelően a gyermekekkel és ifjúsággal foglalkozó szakemberek alapfeladatává teszi a felvilágosítást a gyermeki jogokról, illetve lehetőségeikről a társadalmi részvét szempontjából, a prevenció gyakorlati megvalósulása mindig is háttérbe szorult, az határozza meg, hogy mennyi a mindenképpen szükséges tűzoltás után rendelkezésre álló pénz, erő és energia (Czirják 2008: 35). Pataki és Somorjai (2006) szerint a 


\section{TEMATIKUS TANULMÁNYOK - Társadalmi mobilitás és segítői tevékenység}

gyermekjóléti szolgálatok a törvény életbe lépését követő hosszú idő után is a humán szolgáltatások hierarchiájában alul helyezkednek el. A jelzőrendszer működése a mai napig nem zavartalan, legkritikusabb az együttműködés az egészségügyi szférával. A Rubeus Egyesület (2015) kutatása a gyermekjóléti szolgálatok működése kapcsán is megerősíti, hogy a prevenciós szemlélettel összeegyeztethetetlen módon a szakemberek szinte csak a veszélyeztetett gyermekekkel tudtak foglalkozni. A magas esetszám, a szakemberek eszköztelensége, az összehangolt jogszabályok hiánya és a szakemberek kiégettsége a szektort tartósan jellemzi. A magas esetszám tűzoltásra elég csak, alapos, intenzív családgondozásra, megelőzésre nem. A 2016-tól életbe lépett változásokkal kialakult duális rendszerben a gyermekjóléti alapgondozás és családsegítés egy intézményben kapott helyet, ez a család- és gyermekjóléti szolgálatok szintje, járási szinten pedig a család- és gyermekvédelmi központok látják el a feladatokat. Elvált a családsegítés, amely a gyermekjóléti szolgálat feladata lett és a hatósági munka, amely az esetmenedzserek munkaköre a központok szintjén. A családsegítő és a gyermekjóléti szolgáltatás integrációja a szakmát megosztó folyamat, nincsenek szabványutak, a változás vegyes képet mutat, minden intézmény saját képére igyekezett formálni a segítői tevékenységet (Darvas et al. 2016, Kopasz 2017). A Gyermekvédelmi törvényben megfogalmazott feladatoknak éppen az a része teljesíthetetlen, amelyek a megelőzést és a folyamatos, jó színvonalú gondozást szolgálnák. A gyermekek mobilitási esélyei a szolgáltatások elérhetőségétől és azok minőségétől nagyban függenek.

\section{A gyermekjóléti szolgáltatás mozgástere a szakemberek véleménye szerint}

A vizsgált térségekben összesen 12 interjú készült szakemberekkel, 6-6 a vizsgálati területeken. A megkérdezettek között 1 helyi döntéshozó, 3 intézményvezető, 2 esetmenedzser és 6 családsegítő szerepelt. A félig strukturált interjúk célja a településen elérhető ellátások és szolgáltatások feltérképezése volt, valamint annak megismerése, hogy a szakemberek mit gondolnak az ellátások szakmai minőségéről, a kliensrendszer helyzetéről és hogy véleményük szerint a nyújtott szolgáltatások hogyan tudnak a szociális problémák megoldásához és tágabb értelemben a társadalmi mobilitási esélyek növeléséhez hozzájárulni.

A megkérdezett szakemberek véleménye alapján elmondható, hogy a kistelepülések, kistérségi társulásokban ellátott falvak helyzete, az ott élők számára elérhető szolgáltatások minősége és egyáltalán léte messze alulmarad a városokban meglévő szolgáltatásokhoz képest. A kistelepülésekre jellemző szegénységgel, munkanélküliséggel, szenvedélybetegséggel, iskolai problémákkal, korai terhességgel összefüggő komplex családi problémákat sem a települési, sem pedig a járási, kistérségi társulási szolgáltatások nem tudják kezelni, jellemzően a szakemberhiány miatt. A jelzőrendszer működése és a jelzőrendszeri tagok aktivitása eltérő. Az egyházi, illetve 


\section{TEMATIKUS TANULMÁNYOK - Társadalmi mobilitás és segítői tevékenység}

civil szervezetekkel változó intenzitású kapcsolatban vannak a megkérdezett szakemberek. A magas esetszámok és az ebből fakadó nehézségek minden interjúban megjelentek: a magas esetszám akadályozza a minőségi munkavégzést és nagyban elősegíti a kollégák korai kiégését. A tanácstalanság, eszköztelenség mindenki számára nehézséget okoz. „Több lehetőségek is felmerültek. Valaki azt mondja, hogy több pénz kellene a rendszerbe. Valaki azt mondja, hogy több lehetöség kellene, több hozzáférés." (Észak-magyarországi település esetmenedzsere)

A közös problémákon túl a kliensrendszerben jelentős a különbség. A főváros környéki településeken a gyermekvédelem látókörében megjelennek önkéntes, illetve kötelezett kliensek is. Az önkéntesen érkező kliensekre jellemző anyagi és gyermeknevelési problémák mentén inkább a kevésbé tehetős réteg keresi fel az intézményeket. A kötelezett kliensek között számos jómódú család is van, nagy arányban a válás, iskolai hiányzás, bántalmazás miatt kerülnek kapcsolatba a szolgálattal. A magas presztízsű, jó anyagi helyzetű családokkal való együttműködés nagyon nehéz, hiszen a családok gyakran ügyvédekkel érkeznek az intézménybe, gyakorlatilag nem hozzáférhetők a segítő kapcsolat kialakításához a családok. A családgondozóknak az ügyvédekkel, jogi paragrafusokkal kell megküzdeniük. A hátrányos helyzetű kistérségben egyértelműen a szegénység, az anyagi problémák és iskolai hiányzások jelentik a főbb szociális problémákat, amelyekkel küzdeniük kell.

Mind a fóváros környékén, mind az észak-magyarországi kistérségben az egyik leggyakrabban megjelenő probléma, amely mentén a család kapcsolatba kerül az intézménnyel, az az iskolai hiányzások kérdése. Az iskolai szociális munka kezdetlegesnek mondható. „(...) istenigazából az a nehéz, amikor a gyerek mögül hiányzik a támogató család. És addig, amíg nincs mögötte támogató család, amíg nincs, aki azt mondja, hogy: fiam, neked tanulnod kell vagy fiam, szerezzél meg egy szakmát." (Észak-magyarországi település családgondozója) Az iskolai hiányzások mellett erőteljesen megjelenő probléma a kortárs bántalmazás, illetve jó néhány esetben a családon belüli erőszak. A tapasztalatok szerint a jelzőrendszer ebben a kérdésben erőteljesebben működik, a gyermekekkel találkozó szakemberek, mint pedagógus, orvos, védőnő használják a jelzőrendszert, ha olyan jeleket tapasztalnak, amelyek bántalmazásra utalhatnak. „A gyerekek piszkálják egymást mindenféle fizikai, lelki, egyéb terror előfordul, és abban családon belüli erőszak, apuka üti anyukát, üti esetleg a gyereket. Mostanában serdülőknél nagy divat ez a falcolás..." (Főváros környéki település családgondozója)

A főváros környéki településeken a meglévő bölcsőde, illetve családi napközi és egyéb magánszolgáltatások mellett nem jelent meg kiemelt problémaként a napközbeni kisgyermekellátások hiánya. Ezzel szemben a megkérdezett hátrányos helyzetű kistérség szükségleteinek feltérképezése során az interjúk alapján kirajzolódott a bölcsőde, illetve az alternatív gyermekgondozási intézmények hiánya. A szolgáltatások egészére jellemző a források, elérhető/elnyert pályázatok bizonytalansága és az 


\section{TEMATIKUS TANULMÁNYOK - Társadalmi mobilitás és segítői tevékenység}

ebből fakadó szolgáltatásnyújtási kiszámíthatatlanság, ami megterhelő mind a szolgáltatásokat igénybe vevők, mind a dolgozó szakemberek számára. „Ami fájó, hogy ugye ezek programok. Tehát ez azt jelenti, hogy x éven belül megszünik. És nem vagyok benne biztos, hogy ez jó megoldás, hiszen ha már egyszer megfogták a kezét és elindultak egy úton, nagyon-nagyon szörnyü az, hogy utána pedig a kezüket elengedve ismét magukra vannak." (Észak-magyarországi település alpolgármestere)

A szakemberek szegényes munka- és szolgáltatási körülményekről számoltak be, az interjúkból a magas fluktuáció és a kiégés egyértelműen kitűnik. A kistelepüléseket ellátó szolgálatokra jellemző, hogy az alapvető és törvényileg kötelező szolgáltatásokat sem tudják biztosítani a településen élők számára. „Nálunk három esetmenedzsernek kellene lennie, most jelenleg feltöltés alatt van a létszám nálunk, ugyanígy családsegítőknél, ugyanúgy a központnál. Nyilván nem meglepö, nem csak ebben a szektorban, hanem országos szinten akár az autószerelőkig lemenve hiány van." (Észak-magyarországi település esetmenedzsere) A főváros környéki településeken a meglévő szolgáltatások mellett megjelent a szolgáltatások bővítésének az igénye, de a humánerőforrás-kapacitás növelése nélkül nem tudják a kliensek igényeit megfelelő módon kielégíteni. Több család-, illetve párterápiára lenne szükség, ahogy a meditációk is hatékonyan működnek, de nincs elég szakember, valamint sokat kell várni ezekre a szolgáltatásokra.

A gyermekjóléti alapellátásokból nézve nincs elérhető és jó minőségű nevelőszülői hálózat, nincs elég szakember a gyermekvédelmi szakellátásban, így sem a védelembe vétel, sem a kiemelés megelőzése, illetve a hosszú távú biztonságos gondozás nem tud megvalósulni.

A szakemberek úgy vélik, hogy a jelenlegi szolgáltatásoknak nincs pozitív, társadalmi mobilitást ösztönző hatása. A szolgáltatásokban dolgozók rendelkezésére álló lehetőségek nem elegendőek, hogy a meglévő társadalmi helyzetből érdemben kimozdítsák a gyermekes családokat, a szolgáltatásokat igénybe vevő célcsoport tagjai esetében jellemzően tűzoltásra van erejük és forrásuk. A fejlesztő hatású, jól-létet előmozdítani képes kapcsolt szolgáltatások teljes mértékig hiányosak vagy korlátozott elérésűek mind a felnőtt, mind a gyermekkorú lakosság számára. „Mobilitás szempontjából nem kifejezetten tud hozzásegíteni a központ vagy a települési, járási intézmények a különböző problémával érintett gyermekek mobilitásához, ennek oka a szakemberhiány, a gyermekek, szülők alulmotiváltsága tanulás tekintetében. Nincs megfelelő pedagógus, fejlesztőpedagógus, pszichológus." (Észak-magyarországi település esetmenedzsere) 


\section{TEMATIKUS TANULMÁNYOK - Társadalmi mobilitás és segítői tevékenység}

\section{Családok percepciója a gyermekjóléti ellátásokról}

\section{LAKOSSÁGI VÉLEMÉNYEK AZ EGYES ELLÁTÁSOKRÓL - A KÉRDŐÍVES KUTATÁS EREDMÉNYEI}

Kérdőíves kutatásunk ${ }^{4}$ adatfelvétele két ütemben készült 2018 nyarán és 2019 őszén. Az egyik adatfelvétel az Észak-magyarországi régió egyik hátrányos helyzetű kistérségének különböző településnagyságú területein, a másik a budapesti agglomerációhoz tartozó településeken történt. A hátrányos helyzetű kistérségben készült adatfelvétel a járásban élő gyermeket nevelő családok - ahol a vizsgálat időpontjában élt 0-17 éves korú személy - reprezentatív mintáján készült, rétegzett, véletlen mintaválasztással. A felvett adatok a háztartások összetételének megfelelően súlyozásra kerültek, a minta nagysága a súlyozott adatbázisban 260 fő. Ez az adatfelvétel - a mintavételnek köszönhetően - statisztikai általánosításra alkalmas. A budapesti agglomerációhoz tartozó településeken készült adatfelvétel 62 fő gyermekes család adatait tartalmazza, de kényelmi mintavételből származik ${ }^{5}$, nem alkalmas statisztikai általánosításra. Éppen ezért a következőkben bemutatandó adatok elemzése alapvetően a hátrányos helyzetű térségben készült adatfelvételre épül, a budapesti agglomerációban felvett adatok az elemzéshez kizárólag tájékoztató jellegű, kontroll adatokként szolgálnak. A kérdőíves kutatás célja az egyes egészségügyi, gyermekneveléshez kapcsolódó, oktatási, valamint szociális ellátások ismertségének és ezek igénybevételének feltérképezése volt. A következőkben ezen négy ellátási területen a családok jó-létét, társadalmi integrációját és mobilitási esélyeit meghatározó legfontosabb ellátásokkal kapcsolatos vélekedéseket ismertetjük. A kérdőíves eredmények bemutatását követőn a lakossági interjúkban megfogalmazott főbb álláspontokat összegezzük a szolgáltatások minősége, célelérése szempontjából.

Az egyes ellátások ismertségének és elérhetőségének számba vétele előtt röviden bemutatjuk a két vizsgálati területen élő családokat szocioökonómia jellemzőik mentén.

A hátrányos helyzetű kistérség válaszadóinak 17,1\%-a, míg a kontrolltérség válaszadóinak 14,5\%-a férfi. A városi lakosok aránya a válaszadók között a hátrányos helyzetű térségben lényegesen alacsonyabb (29\%), mint a budapesti agglomerációban (85\%). Az önmagukat roma származásúnak tartók hányada is érdemben eltér a két csoportban: az észak-magyarországi kistérségben élők esetében 24,9\%, a budapesti agglomeráció településein mindössze 1,6\%. A hátrányos helyzetű térségben élő válaszadók 17,1\%-a szegregált lakóhelyen lakik.

\footnotetext{
${ }^{4}$ Az elemzésben Nagy Zita Évával dolgoztunk együtt.

${ }^{5}$ A kényelmi mintavétel nem valószínűségi alapú mintavételi eljárás, amikor az éppen elérhető egyéneket vonjuk be a vizsgálatba. A budapesti agglomerációhoz tartozó településeken azokat kérdeztük meg, akik 0-17 éves gyermeket nevelnek és vállalták a kérdőív kitöltését.
} 


\section{TEMATIKUS TANULMÁNYOK - Társadalmi mobilitás és segítői tevékenység}

\section{EGÉSZSÉGÜGYI SZOLGÁLTATÁSOK ISMERTSÉGE ÉS IGÉNYBEVÉTELE}

A kérdőíves kutatás keretében kíváncsiak voltunk, hogy milyen ellátásokat, szolgáltatásokat ismernek az egészségügy területéről a gyermekes családok. Elmondható, hogy a vizsgált hat ellátás ismertsége tekintetében sokkal rosszabb a helyzet az észak-magyarországi hátrányos helyzetű térségben - az alapvető egészségügyi szolgáltatások észlelt elérhetősége 2,7\% és 95,6\% között mozog, az ellátások perceptív elérhetősége három esetben $50 \%$ alatt van, azaz a gyermekorvos, szakorvos és a kórház elérhetőségéről az adott településen vagy a környékben kevesen tudnak, míg a budapesti agglomerációban csak a kórház érzékelt elérhetősége van $50 \%$ alatt. Megdöbbentő módon 3\% alatt van a kórház ismerete, bár ez a budapesti agglomerációban is aggasztóan alacsony ismertségű (40,3\%). A gyermekes családok esetében az ellátás elérhetőségével kapcsolatos információk hiánya különösen nagy, ha a gyermekorvosokra gondolunk. Pozitívumként említhetjük meg azonban a védőnői szolgáltatás ismertségét mindkét vizsgálati területen.

1. táblázat. Tudomása szerint milyen egészségügyi szolgáltatások, intézmények vannak a településen vagy a környéken? (\%; $N=260$ fö, illetve 62 fö) ${ }^{6}$

\begin{tabular}{|l|c|c|}
\hline & $\begin{array}{c}\text { A szolgáltatást ismerők/tudók } \\
\text { aránya a hátrányos helyzetű } \\
\text { kistérségben (\%) }\end{array}$ & $\begin{array}{c}\text { A szolgáltatást ismerők/tudók } \\
\text { aránya a kontrolltérségben (\%) }\end{array}$ \\
\hline Háziorvos & 95,6 & 100 \\
\hline Gyermekorvos & 43 & 93,5 \\
\hline Védőnő & 93,7 & 96,8 \\
\hline Gyógyszertár & 76,3 & 98,4 \\
\hline Szakorvos & 32,6 & 87,1 \\
\hline Kórház & 2,7 & 40,3 \\
\hline
\end{tabular}

Forrás: Saját szerkesztés

Megkérdeztük azt is, hogy a vizsgált szolgáltatásokat igénybe is vették-e. Nagyon érdekes, hogy az elérési különbségek ellenére az igénybevétel a háziorvos, a gyermekorvos és a kórház esetében különbözött érdemben a két vizsgálati helyszínen. A hátrányos helyzetű térségben a háziorvos és a kórház igénybevétele a lakosság kedvezőtlenebb egészségügyi állapotát jelezheti, a gyermekorvos igénybevétele esetében megfigyelhető különbség viszont inkább az ellátáshiány miatt lehetséges.

${ }^{6}$ A következőkben bemutatásra kerülő ismertségre és igénybevételre vonatkozó elemzésekhez az adatokat kereszttáblába rendeztük és mivel $2 \times 2$-es táblák, ezért Fisher-féle Exact Testet végeztünk. 
www. metszetek.unideb.hu

\section{TEMATIKUS TANULMÁNYOK - Társadalmi mobilitás és segítői tevékenység}

2. táblázat. A szolgáltatást igénybe vevők aránya (\%; N=260fő, illetve 62 fő)

\begin{tabular}{|l|c|c|}
\hline & $\begin{array}{c}\text { A szolgáltatást igénybe vevők } \\
\text { aránya a hátrányos helyzetű } \\
\text { kistérségben (\%) }\end{array}$ & $\begin{array}{c}\text { A szolgáltatást igénybe vevők } \\
\text { aránya a kontrolltérségben (\%) }\end{array}$ \\
\hline Háziorvos & 87,3 & 69,4 \\
\hline Gyermekorvos & 65,4 & 83,9 \\
\hline Védőnő & 78,4 & 85,5 \\
\hline Gyógyszertár & 76,7 & 80,6 \\
\hline Szakorvos & 48,9 & 50 \\
\hline Kórház & 41 & 24,2 \\
\hline
\end{tabular}

Forrás: Saját szerkesztés

GYERMEKNEVELÉSSEL KAPCSOLATOS SZOLGÁLTATÁSOK, INTÉZMÉNYEK ISMERTSÉGE ÉS IGÉNYBEVÉTELE

A gyermekek nevelésével kapcsolatban 5 szolgáltatás ismertségét és igénybevételét vizsgáltuk. Fontos megjegyezni, hogy bár az óvoda köznevelési intézmény, a gyermekes családok támogatása szempontjából annak gyermeknevelési, szocializációs funkciója miatt ide soroltuk.

Az óvodai szolgáltatás ismerete a településen vagy a környéken gyakorlatilag általánosnak tekinthető mindkét térségben. A többi szolgáltatás esetében azonban jelentős különbségek figyelhetők meg a hátrányos helyzetű és a budapesti agglomerációba tartozó családok véleménye között. Különösen jelentősek a különbségek a bölcsőde (a kontroll térségben mintegy 60,1\%-kal magasabb az ilyen szolgáltatást ismerők aránya), illetve a gyermekpszichológus (58,7\% a különbség) és a nevelési tanácsadó (43,4\% a különbség) esetében. A gyerekház, mely hátrányos helyzetü gyermekek számára létrejött szolgáltatás, kivételt képez, hiszen a perceptív elérés a hátrányos helyzetű régióban a budapesti agglomerációhoz képest jóval magasabb, 71,1\%, szemben a budapesti agglomerációban mért 46,8\%-kal. 


\section{TEMATIKUS TANULMÁNYOK - Társadalmi mobilitás és segítői tevékenység}

3. táblázat. Tudomása szerint milyen gyermekneveléssel kapcsolatos szolgáltatások, intézmények vannak a településen vagy a környéken? (\%; N=260fö, illetve 62 fó)

\begin{tabular}{|l|c|c|}
\hline & $\begin{array}{c}\text { A szolgáltatást ismerők aránya a } \\
\text { hátrányos helyzetű kistérségben } \\
(\%)\end{array}$ & $\begin{array}{c}\text { A szolgáltatást ismerők ará- } \\
\text { nya a kontrolltérségben (\%) }\end{array}$ \\
\hline Bölcsőde & 36,7 & 96,8 \\
\hline Gyerekház & 71,1 & 46,8 \\
\hline Óvoda & 96,2 & 100 \\
\hline Nevelési tanácsadás & 32,4 & 75,8 \\
\hline Gyermekpszichológus & 12,3 & 71 \\
\hline
\end{tabular}

Forrás: Saját szerkesztés

Az igénybevétel megdöbbentő képet mutat, az óvodán kívül valamennyi gyermeknevelést segítő szolgáltatás igénybevétele nagyon alacsony. A hátrányos helyzetű régióban lényegesen kedvezőtlenebb a helyzet a budapesti agglomerációhoz képest az ellátások igénybevétele vonatkozásában, hiszen mindössze a válaszadók közel ötöde $(19,4 \%)$ vesz igénybe bölcsődét (ez a kontrolltérségben a válaszadók harmadára igaz), közel minden tizedik (12\%) válaszadó nevelési tanácsadást (a kontrolltérségben ez nagyjából minden ötödik válaszadóra igaz), és minden huszadik (4,8\%) gyermekpszichológust (a kontrolltérségben ez minden negyedik válaszadóra igaz). A gyerekház az igénybevétel tekintetében is kiemelkedő a hátrányos helyzetű térségben, elmondható, hogy minden harmadik (35,7\%) szülő jelezte, hogy igénybe veszi, míg a kontrolltérségben ez csak minden hatodik válaszadóra igaz.

4. táblázat. A szolgáltatást igénybe vevők aránya (\%; N=260fő, illetve 62 fő)

\begin{tabular}{|l|c|c|}
\hline & $\begin{array}{c}\text { A szolgáltatást igénybe vevők } \\
\text { aránya a hátrányos helyzetű } \\
\text { kistérségben (\%) }\end{array}$ & $\begin{array}{c}\text { A szolgáltatást igénybe vevők } \\
\text { aránya a kontrolltérségben (\%) }\end{array}$ \\
\hline Bölcs̋őde & 19,4 & 33,9 \\
\hline Gyerekház & 35,7 & 16,1 \\
\hline Óvoda & 70,4 & 74,2 \\
\hline Nevelési tanácsadás & 12 & 22,6 \\
\hline Gyermekpszichológus & 4,8 & 25,8 \\
\hline
\end{tabular}

Forrás: Saját szerkesztés 


\section{TEMATIKUS TANULMÁNYOK - Társadalmi mobilitás és segítői tevékenység}

\section{OKTATÁSI INTÉZMÉNYEK ISMERTSÉGE ÉS IGÉNYBEVÉTELE, VALAMINT TANULÁSI LEHETŐSÉGEK}

Az oktatási intézmények elérhetősége, ismertsége és igénybevétele nagyban meghatározza, hogy milyen életkilátásai vannak a gyermekeknek. Ebben a blokkban öt segítségnyújtási formát, intézményt választottunk ki, kitérve a középfokú továbbtanulási és nyelvtanulási lehetőségekre is.

A gyakorlatilag teljes körben ismert általános iskolák mellett érdekes, hogy a hátrányos helyzetű diákok felzárkózását biztosító tanodák esetében sincs érdemi különbség az észlelt elérés tekintetében a vizsgált hátrányos helyzetű térség és a budapesti agglomeráció között. A társadalmi mobilitás szempontjából kulcsfontosságúnak számító továbbtanulási lehetőségek (a budapesti agglomerációban 82,3\%, míg a hátrányos helyzetű térségben $20,8 \%$ az észlelt elérés); a kollégiumi elhelyezés lehetősége (a hátrányos helyzetű térségben 22,5\%, a budapesti agglomerációban 9,7\% az észlelt elérés); valamint a nyelvtanulási lehetőségek (a budapesti agglomerációban 90,3\%, míg a hátrányos helyzetű térségben 32,6\% az észlelt elérés) esetében azonban égetőek a különbségek. Pozitívumnak tekinthető a kollégiumok esetében, hogy az ismertség a hátrányos helyzetű térségben kétszer több, ennek gyermekjóléti relevanciája is van a veszélyeztető tényezők megelőzése vagy elhárítása vonatkozásában. Köztudott, hogy a gyermek családból való kiemelésének elkerülésére is kiváló megoldás. A főváros környékén az utazási lehetőségek kiépítettsége megoldást jelent, ezért is lehet, hogy kevésbé van a szülőknek erről információja. Érdemes azonban kihangosítanunk, hogy közel négyszeres a továbbtanulási lehetőségek ismerete és háromszoros a nyelvtanulási lehetőségekről való tájékozottság, ami a gyermekek jövőbeli kilátásait nagyban meghatározhatja.

5. táblázat. Tudomása szerint vannak-e a településen vagy a környéken oktatási intézmények, tanulási lehetőségek? (\%; N=260 fö, illetve 62 fó)

\begin{tabular}{|l|c|c|}
\hline & $\begin{array}{c}\text { A szolgáltatást ismerők aránya a } \\
\text { hátrányos helyzetű kistérségben } \\
(\%)\end{array}$ & $\begin{array}{c}\text { A szolgáltatást ismerők } \\
\text { aránya a kontrolltérségben } \\
(\%)\end{array}$ \\
\hline Általános iskola & 97,4 & 100 \\
\hline Tanoda & 19,7 & 14,5 \\
\hline Továbbtanulás & 20,8 & 82,3 \\
\hline Kollégium & 22,5 & 9,7 \\
\hline Nyelvtanulási lehetóség & 32,6 & 90,3 \\
\hline
\end{tabular}

Forrás: Saját szerkesztés 


\section{TEMATIKUS TANULMÁNYOK - Társadalmi mobilitás és segítői tevékenység}

Bár az észlelt elérés esetében jelentős különbségek mutatkoztak a továbbtanulást segítő lehetőségek vonatkozásában, az adatok azt jelzik, hogy a valós igénybevétel esetében nincs érdemi különbség a hátrányos helyzetű és a kontrolltérség válaszadói között. Ez azt jelenti, hogy bár alacsony az igénybevétel a kollégium és a középiskolai továbbtanulás kiaknázása terén a megkérdezett családok körében, úgy tűnik, hogy akinek szüksége van rá, megtalálja az adott szolgáltatást. A nyelvtanulási lehetőség azonban kivételt képez, elmondható, hogy várakozásainkhoz mérten a budapesti agglomerációban nagyobb arányban veszik igénybe a nyelvi képzéseket: 33,9\%, szemben a hátrányos helyzetű térségben megfigyelhető 19,8\%-kal. A tanoda nagyon érdekes képet mutat, közel 20\%-os ismertsége ellenére közel 7\% veszi igénybe a hátrányos helyzetű térségben, ahol ennek komoly hátránykompenzáló szerepe lehet, mint ahogy a tehetséggondozásban is kiemelt jelentőséggel bírhat.

6. táblázat. A szolgáltatást igénybe vevők aránya (\%; N=260fö, illetve 62 fő)

\begin{tabular}{|l|c|c|}
\hline & $\begin{array}{c}\text { A szolgáltatást igénybe vevők } \\
\text { aránya a hátrányos helyzetű } \\
\text { kistérségben (\%) }\end{array}$ & $\begin{array}{c}\text { A szolgáltatást igénybe vevők } \\
\text { aránya a kontrolltérségben } \\
(\%)\end{array}$ \\
\hline Általános iskola & 62,2 & 61,3 \\
\hline Tanoda & 6,8 & 1,6 \\
\hline Továbbtanulás & 17,1 & 21 \\
\hline Kollégium & 6,6 & 1,6 \\
\hline Nyelvtanulási lehetőség & 19,8 & 33,9 \\
\hline
\end{tabular}

Forrás: Saját szerkesztés

\section{SZOCIÁLIS SZOLGÁLTATÁSOK ISMERTSÉGE ÉS IGÉNYBEVÉTELE}

Vizsgáltunk néhány szociális típusú szolgáltatást is, ezekből 3 speciális élethelyzetre fókuszáló, de azt gondoltuk, hogy nagyon fontos a mobilitási esélyek szempontjából, hogy a gyermekes családnak van-e idős, fogyatékkal élő és szenvedélybeteg-ellátási igénybevétele. A család- és gyermekjóléti szolgáltatás, adósságkezelés a családi élethelyzetek rendezését hivatott szolgálni, beleértve az anyagi helyzet rendezését is, mint ahogy a gyermekétkeztetés is a szegénység enyhítésének eszköze. A gyermekjóléti szolgáltatás természetesen szélesebb problémakörre képes reagálni, ennek fókuszában a gyermek családon belüli veszélyeztetettségének megelőzése, valamint megszüntetése áll, célja, hogy a gyermek a saját családban nevelkedhessen.

Elmondható a vizsgált hat szolgáltatásról, hogy ezek közül 3, a családsegítő szolgáltatás, az idősek klubja és a gyermekek nyári étkeztetése mindkét vizsgálati térségben széles körben ismert szolgáltatások, bár a gyermekek nyári étkeztetése 


\section{TEMATIKUS TANULMÁNYOK - Társadalmi mobilitás és segítői tevékenység}

esetében a hátrányos helyzetű térségben magasabb érdemben az észlelt elérés, feltehetően a súlyosabb anyagi helyzetek miatt.

A fogyatékos embereket és szenvedélybeteget segítő szolgáltatások perceptív elérése esetében azonban nagyok a térségek közötti különbségek: a budapesti agglomerációban mintegy hatszor annyian tudják, hogy vannak fogyatékos embereket és mintegy négyszer annyian, hogy léteznek szenvedélybetegséggel küzdőket segítő szolgáltatások. Mindenképpen pozitívként kell megemlíteni, hogy a családsegítő és gyermekjóléti szolgáltatásról való információ a megkérdezettek háromnegyedét eléri mindkét vizsgálati területen.

7. táblázat. Vannak-e olyan szolgáltatások, ahová szociális problémák esetén fordulhat valaki? (\%; $N=260$ fó, illetve 62 fó)

\begin{tabular}{|l|c|c|}
\hline & $\begin{array}{c}\text { A szolgáltatást ismerők } \\
\text { aránya a hátrányos helyzetű } \\
\text { kistérségben (\%) }\end{array}$ & $\begin{array}{c}\text { A szolgáltatást ismerók } \\
\text { aránya a kontrolltérségben } \\
(\%)\end{array}$ \\
\hline $\begin{array}{l}\text { Családsegítő és gyermekjóléti } \\
\text { szolgálat }\end{array}$ & 77,3 & 91,9 \\
\hline Adósságkezelés & 16,3 & 14,5 \\
\hline Gyermekek nyári étkeztetése & 85,2 & 61,3 \\
\hline Fogyatékos emberek segítése & 8,7 & 46,7 \\
\hline $\begin{array}{l}\text { Szenvedélybeteg emberek } \\
\text { segítése }\end{array}$ & 3,8 & 16,2 \\
\hline Idősek klubja & 66,1 & 85,5 \\
\hline
\end{tabular}

Forrás: Saját szerkesztés

A vizsgált szociális ellátások igénybevételét tekintve érdemi különbség a gyermekek nyári étkeztetése, valamint a családsegítő szolgáltatás esetében mutatkozik. A családsegítés kapcsán ugyanis a hátrányos helyzetű térségben az igénybevétel aránya több mint duplája a budapesti agglomerációban megfigyelhető igénybevételi aránynak. Az adósságkezelés, az időseket, fogyatékkal élőket és szenvedélybetegeket célzó szolgáltatások esetében viszont nem mutatható ki érdemi különbség. 
www. metszetek.unideb.hu

\section{TEMATIKUS TANULMÁNYOK - Társadalmi mobilitás és segítői tevékenység}

8. táblázat. A szolgáltatást igénybe vevők aránya (\%; N=260 fő, illetve 62 fő)

\begin{tabular}{|l|c|c|}
\hline & $\begin{array}{c}\text { A szolgáltatást igénybe vevők } \\
\text { aránya a hátrányos helyzetű } \\
\text { kistérségben (\%) }\end{array}$ & $\begin{array}{c}\text { A szolgáltatást igénybe vevők } \\
\text { aránya a kontrolltérségben } \\
(\%)\end{array}$ \\
\hline $\begin{array}{l}\text { Családsegító és } \\
\text { gyermekjóléti szolgálat }\end{array}$ & 25 & 11,3 \\
\hline Adósságkezelés & 5 & 0 \\
\hline $\begin{array}{l}\text { Gyermekek nyári } \\
\text { étkeztetése }\end{array}$ & 33 & 0 \\
\hline $\begin{array}{l}\text { Fogyatékos emberek } \\
\text { segítése }\end{array}$ & 0,5 & 3,2 \\
\hline $\begin{array}{l}\text { Szenvedélybeteg emberek } \\
\text { segítése }\end{array}$ & 0,5 & 0 \\
\hline Idősek klubja & 8,9 & 4,8 \\
\hline
\end{tabular}

Forrás: Saját szerkesztés

Fontosnak tartottuk megnézni azt is, hogy kik veszik igénybe az adott szolgáltatásokat. Jelen elemzésünkben csak a családsegítő és gyermekjóléti szolgáltatásra helyezzük a hangsúlyt és csak a reprezentatív mintára irányulóan, mely a hátrányos helyzetű kistérségben megkérdezett családokra vonatkozik. A válaszadók háztartásainak jövedelmi viszonyait, illetve kirekesztettségét több - a nemzetközi standardoknak megfelelő - mutatóval is mértük. Az adatokat kereszttáblába rendezve azt vizsgáltuk, hogy a különböző egyéni, háztartási és lakóhelyi jellemzőkkel rendelkező családok csoportjaiban érdemben eltérő-e az adott szolgáltatások igénybevétele? Csoportképző tényezőként a következőket használtuk: 1) Egyéni jellemzők: a válaszadó neme; roma származású-e; 2) Háztartás jellemzői: jövedelmi szegénység $(\mathrm{OECD} 2)^{7}$; súlyos depriváció ${ }^{8}$; legmagasabb iskolai végzettség a háztartásban; háztartás munkaerőpiaci részvételének típusa ${ }^{9}$; anya korai iskolaelhagyó-e; substandard-e a lakás ${ }^{10}$; 3) Lakóhely jellemzői: település típusa; szegregátumban van-e a lakóhely ${ }^{11}$.

\footnotetext{
${ }^{7}$ Jövedelmi szegénység: a medián jövedelem 60\%-a (medián jövedelem = teljes népességet OECD 2 fogyasztási egységre jutó jövedelem alapján sorba rendezik, és a sor közepén lévő jövedelem jelenti a mediánt, vagyis hozzá képest pontosan ugyanannyi embernek van kevesebb, illetve több jövedelme).

${ }^{8}$ A depriváció mérésekor azt vizsgálják, hogy egy standard ( 9 elemű) szükségletlistából a családban hány elem biztosított. Négy vagy annál több kielégítetlen szükséglet eseten beszélünk súlyos deprivációról.

${ }^{9}$ Három értéket határoztunk meg: nincs foglalkoztatott; csak közmunkás/alkalmi munkás foglalkoztatott van; van foglalkoztatott a háztartásban.

${ }^{10}$ Substandard lakás az, amelyikben nincs vezetékes víz vagy nincs benne WC/fürdőszoba vagy az alapterülete nem éri el az $50 \mathrm{~m}^{2}$-t.

${ }^{11}$ A vizsgált hátrányos helyzetű észak-magyarországi térség esetében 5 településen jellemző a lakóhelyi elkülönülés. A 2018-as Helyi Esélyegyenlőségi Program szerint ez a családok 17\%-át jelenti, közel 80\%-uk roma származású, 70\%-uk pedig szegénységben él.
} 


\section{TEMATIKUS TANULMÁNYOK - Társadalmi mobilitás és segítői tevékenység}

Az OECD jövedelmi szegénységre vonatkozó definíciója szerint jövedelmi szegénynek a válaszadók 31,7\%-a tekinthető, súlyosan deprivált pedig 17,4\%. Substandard lakásban 18,1\%-uk él. A társadalmi kirekesztettség meghatározó tényezője az iskolai végzettség, illetve a munkaerőpiaci részvétel. A válaszadók több mint harmada olyan háztartásban él, ahol legfeljebb 8 általános a legmagasabb végzettség $(35,9 \%)$, kb. negyedük esetében van szakmával $(23,4 \%)$, illetve érettségivel $(23,2 \%)$ rendelkező háztartástag, míg a diplomás háztartástaggal rendelkező válaszadók aránya 17,5\%. A vizsgált háztartások 13,3\%-ában az édesanya korai iskolaelhagyónak tekinthető; 6,3\%-ban egyáltalán nincs foglalkoztatott, míg 21\% esetében csak alkalmi munkás vagy közmunkás él a háztartásban. A 9. táblázat azt mutatja, hogy a vizsgált hátrányos helyzetű térségben kikre jellemző a családsegítő és gyermekjóléti szolgáltatás igénybevétele.

9. táblázat. A szolgáltatások igénybevétele a különböző csoportokban a vizsgált hátrányos helyzetű térségben ( $\mathrm{N}=260$ fő)

\begin{tabular}{|c|c|c|c|}
\hline & $\begin{array}{l}\text { Alkalmazott teszt/ } \\
\text { értéke }\end{array}$ & Sig. & Mi jellemző? \\
\hline \multicolumn{4}{|c|}{ Családsegítő és gyermekjóléti szolgálat } \\
\hline Roma származás & Fisher-féle Exact Test & 0.000 & $\begin{array}{l}\text { A roma háztartásokban mintabeli ará- } \\
\text { nyukhoz képest nagyobb arányban vették } \\
\text { igénybe a szolgáltatást. }\end{array}$ \\
\hline Jövedelmi szegénység & Fisher-féle Exact Test & 0.03 & $\begin{array}{l}\text { A szegények a mintabeli arányukhoz } \\
\text { képest nagyobb arányban vették igénybe } \\
\text { a szolgáltatást. }\end{array}$ \\
\hline Súlyos depriváció & Fisher-féle Exact Test & 0.001 & $\begin{array}{l}\text { A súlyosan depriváltak a mintabeli ará- } \\
\text { nyukhoz képest nagyobb arányban vették } \\
\text { igénybe a szolgáltatást. }\end{array}$ \\
\hline $\begin{array}{l}\text { Legmagasabb iskolai } \\
\text { végzettség a háztar- } \\
\text { tásban }\end{array}$ & $\begin{array}{l}\text { Pearsons } \lambda^{2} \text { test } \\
(16.622)\end{array}$ & 0.001 & $\begin{array}{l}\text { Minél alacsonyabb a háztartásban a } \\
\text { legmagasabb végzettség, a mintabeli ará- } \\
\text { nyukhoz képest nagyobb arányban vették } \\
\text { igénybe a szolgáltatást. }\end{array}$ \\
\hline Substandard lakás & Fisher-féle Exact Test & 0.000 & $\begin{array}{l}\text { A substandard lakásban élők a mintabeli } \\
\text { arányukhoz képest nagyobb arányban } \\
\text { vették igénybe } \\
\text { a szolgáltatást. }\end{array}$ \\
\hline $\begin{array}{l}\text { Munkaerópiaci } \\
\text { részvétel típusa }\end{array}$ & $\begin{array}{l}\text { Pearsons } \lambda^{2} \text { test } \\
(20.381)\end{array}$ & 0.000 & $\begin{array}{l}\text { Azok a háztartások, ahol nincs foglal- } \\
\text { koztatott, illetve ahol alkalmi munkás / } \\
\text { közmunkás van, a mintabeli arányukhoz } \\
\text { képest nagyobb arányban vették igénybe } \\
\text { a szolgáltatást. }\end{array}$ \\
\hline $\begin{array}{l}\text { Anya korai } \\
\text { iskolaelhagyó-e }\end{array}$ & Fisher-féle Exact Test & 0.019 & $\begin{array}{l}\text { Azok a háztartások, ahol az anya korai } \\
\text { iskolaelhagyó, nagyobb arányban vették } \\
\text { igénybe a szolgáltatást. }\end{array}$ \\
\hline Településtípus & Fisher-féle Exact Test & 0.04 & $\begin{array}{l}\text { A községben élők a mintabeli arányukhoz } \\
\text { képest kissé nagyobb arányban vették } \\
\text { igénybe a szolgáltatást. }\end{array}$ \\
\hline
\end{tabular}

Forrás: Saját szerkesztés 


\section{TEMATIKUS TANULMÁNYOK - Társadalmi mobilitás és segítői tevékenység}

A családsegítő által nyújtott szolgáltatások igénybevételét vizsgálva elmondható, hogy a leginkább rászorulókat éri el: a mintabeli arányuknál nagyobb arányban veszik igénybe a romák, a szegények, a súlyosan depriváltak, a községben élők, illetve az alacsonyabb iskolai végzettséggel rendelkező, foglalkoztatott nélküli vagy közmunkás családtaggal rendelkező háztartások. Ez egyfelől mutathat egy sikeres célelérést, de egyben kritikája is a rendszernek, hiszen a jóléti lába, a prevenciós megoldások tárháza igen szűkös, melyre a szakemberek is rámutattak. Tűzoltásra épül a rendszer.

Megkérdeztük azt is, hogy van-e és ha igen, milyen problémája a gyermekes családoknak, amiben jó lett volna segítséget kapniuk, de az adott településen vagy a közelben nem volt rá lehetőségük. A válaszok alapján 10\%-nál többen említették (legalább 25 említés) az alapvető egészségügyi intézmények és szolgáltatások hiányát, mint orvos, gyermekorvos, laborvizsgálat, kórház hiánya, illetve a közlekedést (rossz utak, ritka járatok települések között), 5-10\% közötti említést (10-25 említés) kapott a munkalehetőségek és a pénzbeli támogatások, segélyek hiánya. Kevesebb említést kapott, de több válaszadó említette a természetbeni támogatások hiányát, mint tüzelő, önkormányzati lakás, a speciális szakemberek, fejlesztések hiányát, mint pszichológus, gyermekpszichológus, gyógytornász. Néhányan olyan szolgáltatást neveztek meg, mint élelmiszerboltok, üzletek, játszótér vagy sportolási lehetőség. A budapesti agglomerációban csak a közlekedéssel kapcsolatban születtek válaszok.

\section{TERÜLETI KÜLÖNBSÉGEK A TÁRSADALMI MOBILITÁSI LEHETŐSÉGEK TEKINTETÉBEN A SZÜLŐK VÉLEMÉNYE ALAPJÁN}

A kérdőíves felméréshez társítva 102 rövid interjút is készítettünk. 62 db készült Budapest agglomerációjában, emellett a hátrányos helyzetű kistérség több kisebb településén 40 interjú. Ahol a kérdezettek vállalták a kérdőív kitöltéséhez kapcsolódóan a rövid interjút, ott igyekeztünk megtudni, hogy mit gondolnak a helyi szociális, egészségügyi és oktatási rendszer helyzetéről, állapotáról és arról, hogy ezek számukra miben, milyen problémák esetén tudnak segítségükre lenni. Az interjúk hossza 5-15 perc volt a legtöbb esetben.

Általánosan elmondható, hogy minden szolgáltatás tekintetében, az egészségügy, az oktatás, a munkaerőpiac és a kulturális területen is hatalmas különbség tapasztalható a két vizsgált térség között a családok véleménye szerint.

A budapesti agglomerációhoz tartozó települések megfelelően ellátottak a különböző szolgáltatások tekintetében, a kérdezettek úgy vélik, van elérhető háziorvos, gyermekorvos. Elérhetőek a szűrővizsgálatok, a fogorvos, a terhesgondozás, a védőnő és a szakorvosi rendelések is a településeken. A gyermekekkel kapcsolatos 


\section{TEMATIKUS TANULMÁNYOK - Társadalmi mobilitás és segítői tevékenység}

szolgáltatásokról is elmondható, hogy van bölcsőde, óvoda, több iskola is a településeken. Középfokú oktatási intézmény egy-két településen érhető el helyben. A lokációból következően a településeken van fizetőképes kereslet, így a magán oktatási és egészségügyi szolgáltatások is könnyedén elérhetőek. A településeken vannak sportegyesületek, könyvtár, kulturális lehetőségek fizetős és ingyenes formában egyaránt.

Az egészségügy területén jelent meg az interjúk alapján leginkább az a tendencia, hogy a megfelelő szolgáltatás érdekében a megkérdezettek a magánellátások közül választanak maguknak, ily módon többen nem rendelkeztek információval az állami fenntartású, helyben megtalálható intézményekkel kapcsolatban, hiszen nem használják ezeket. Az egészségügyi szereplőkkel kapcsolatos tapasztalataik zömmel pozitívak voltak, az orvosokkal és a védőnőkkel inkább elégedettek a megkérdezettek, bár kiemelték, hogy nagyon változó hozzáállású és tudású szakemberekkel találkoztak. Az állami szolgáltatások minőségével kapcsolatban a megkérdezettek elégedettsége nagyban az adott szakember személyétől függ. Kritikaként fogalmazódott meg a vizsgálatokra történő hosszú előjegyzés és foglalt időpont esetén is a hosszú várakozás a helyszínen. „Háziorvos van, alapos a doktor néni. Van fogászat, azzal is elégedett voltam, egy nagyon jó fogorvost sikerült itt alkalmaznia az önkormányzatnak. Akkor van egy pár magánrendelés is..." (Budapesti agglomerációhoz tartozó településen élő család)

Azokban a kisebb falvakban, ahol az interjúalanyok élnek, a szülői perspektíva alapján minimális helyi ellátást, szolgáltatást lehet megtalálni az észak-magyarországi kistérségben. Magánpiaci szolgáltatást ezeken a településeken senki sem tud megfizetni, így kereslet hiányában nincs is piaci szegmens elérhető távolságban és módon. Az egészségügyi szolgáltatások terén helyben csak háziorvos áll rendelkezésre. A háziorvos megítélése vegyesnek mondható, sokan elégedettek vele, de többen fogalmaztak meg kritikát a hosszú várakozás és a kiszámíthatatlan rendelési idő okán. A védőnő hetente egyszer jár a településre, de összességében az interjúalanyok szerint a védőnő elérhető a falvakban a lakók számára. A védőnő személyét jellemzően elfogadják, lehet tőle tanácsot kérni, segít, ha probléma van a kisgyermekekkel. „Ő minden szerdán jön ide ki, neki is van egy külön hely, ahova kijár itten. Tök rendes, lehet vele beszélni, ellássa a feladatát, járkál így házakhoz, hogy megnézze, milyen körülmények közt élnek a gyerekek, vagy ha csecsemöt hoznak haza, akkor kiszáll a házhoz, úgyhogy tök jó." (Észak-magyarországi kistérség településén élő család)

Általánosan nagyon rossz véleménnyel van mindenki az ügyelettel kapcsolatban, nem jön ki az ügyeletes orvos, ha ki is jön, nem hajlandó megvizsgálni a beteget alaposan. Több interjúalany véleménye szerint van olyan ügyeletes orvos, aki ittas állapotban dolgozik, illetve nem titkoltan rasszista megjegyzéseket tesz. Emiatt az ügyeleti időben, aki teheti, inkább mentőt hív, vagy bemegy a közeli városban található ügyeletes kórházba. A falvakhoz közeli kórházban működő szakrendelé- 


\section{TEMATIKUS TANULMÁNYOK - Társadalmi mobilitás és segítői tevékenység}

sekről és szűrővizsgálatokról kevés információval rendelkeznek az interjúalanyok, nem szívesen mennek el ezekre a rendelésekre, csak ha komoly problémájuk van. Bővebb, mélyebb információjuk a gyermekorvosi ellátással és terhesgondozással kapcsolatban van kizárólag. Nagyon orvosfüggő, hogy milyen tapasztalatokkal és élményekkel rendelkeznek, összességében inkább negatív, mint pozitív ezeknek az ellátásoknak a megítélése. „Hát nem vagyok vele megelégedve sajnos. Meg elég sok kisgyerek is van, és meg is van a helye, ahova kijönne egy gyerekorvos, de most nincs. Egy háziorvos van, aki mindenkit ellát." (Észak-magyarországi kistérség településén élő család)

Az oktatási rendszerrel, gyermekeknek szóló szolgáltatásokkal kapcsolatban inkább pozitív a mérleg a budapesti agglomerációban. Itt is erősen megjelenik a magánbölcsődét, családi napközit, óvodát választók száma. Akik az állami szolgáltatásokat veszik igénybe, közöttük nagyobb a szolgáltatásokkal kapcsolatos elégedetlenség. Ennek okai: a pedagógusok körében jellemző fluktuáció magas mértéke, nem megfelelő szakemberi viselkedés, magasfokú kiégettség, gyermekekkel szembeni elfogadhatatlan bánásmód, pl. kiabálás, érzéketlenség, érdeklődés hiánya. Az iskolaválasztásnál erőteljesen érvényesül, hogy a körzetes iskola helyett más, gyakran egyházi intézményt keresnek gyermekeik számára. Ez a különbségtétel az óvodára még nem jellemző. Az interjúalanyok nagy része, amennyiben szükségesnek ítélte, magántanárt, korrepetálást fizet meg gyermeke számára, ilyen típusú szolgáltatások is elérhetőek ezeken a településeken.

A gyermekekhez kapcsolódó szolgáltatások tekintetében a hátrányos helyzetű kistérség falvaiban bölcsődei ellátás nincs. Egy gyermekház, egy óvoda és általános iskola van a településeken. Nyelv- és zenetanulási lehetőségre nincs mód. A gyermekházat sokan nagyon szeretik, babaháznak hívják, szívesen járnak oda gyermekükkel, mások viszont negatív véleménnyel vannak, szerintük csak kevesen használják az intézményt. Azt többen nehezményezték, hogy a gyermekház udvarán található játszótér csak nyitvatartási időben érhető el, másik játszótér viszont nincs elérhető távolságban. „Járnak, hát általában olyan 15-20 gyerek simán, föleg mikor ilyen összejövetelek, húsvétkor tojásfestés, virágok, meg mit tudom én micsodák, nőnap, minden ilyet tartanak és sokan szoktak járni. Karácsonykor is, amikor voltunk, voltak vagy 25-en biztos." (Észak-magyarországi kistérség településén élő család)

Általánosan elmondható, hogy a budapesti agglomerációhoz tartozó településeken sokan választják azt, hogy a különböző szolgáltatásokat inkább a fővárosban veszik igénybe mind az egészségügy, mind az oktatás és foglalkoztatás terén. Az agglomerációs övezetre jellemző, hogy jó az úthálózat és a tömegközlekedés. A buszok gyakran járnak, a nap minden szakaszában. Sokan Budapestről költöztek ki ezekre a településekre és a kiköltözés ellenére orvoshoz, iskolába és dolgozni is változatlanul Budapestre járnak. „Ha Pest vonzáskörzetében nézed a dolgokat, az embereknek sze- 


\section{TEMATIKUS TANULMÁNYOK - Társadalmi mobilitás és segítői tevékenység}

rintem 70-80\%-a, a város fele megy dolgozni." (Budapesti agglomerációhoz tartozó településen élő család)

A szociális ellátórendszert a megkérdezettek nagy része nem ismeri és nem használja a budapesti agglomerációban. A családsegítőt mint intézményt ugyan ismerik, hallottak róla, megtudták még páran nevezni a településen működő fogyatékkal élők támogatását célzó intézményt, illetve a szenvedélybetegek számára nyújtott szolgáltatást. Szociális intézménnyel kevesük került kapcsolatba, a véleményük inkább negatív, mint pozitív volt. Álláspontjuk szerint nem kompetensek az ott dolgozó szakemberek, nem tudnak érdemben segíteni a problémák megoldásában.

Az észak-magyarországi kistérségre jellemző hátrányos helyzet és nagyfokú szegénység ellenére nincs jelen érdemben szociális szakember ezekben a falvakban a gyermekes családok segítésére. Az önkormányzatot említik, ahova pénzbeli és természetbeli támogatásért lehet fordulni, illetve családi és baráti kapcsolataikat, akikre támaszkodnak, ha bajban vannak. Az interjúkban az önkormányzat jelenik meg mint a segélyekért felelős hivatal, a gyámügy pedig mint hatóság, amihez egyértelműen félelemérzet kötődik, hogy elveszik a gyermeküket. A gyámügytől nem válik el funkciójában a gyermekjóléti szolgálat, de minden alap- és speciális szociális szolgáltatás korlátozottan van jelen az interjúalanyok narratívájában. „Hát a hivatalban ott vannak, aki foglalkozik, ne adj isten gyámüggyel, van ez a lakfenntartási, gyermekétkeztetés. Ott a hivatalban megvan ugye az adott ügyintéző, formanyomtatványt kitölti, ott is ugye az anyagi helyzetet hivatalosan le kell írni és ott elbírálják, hogy jogos-e vagy sem." (Észak-magyarországi kistérség településén élő család)

Ahogy az alábbi párbeszéd is mutatja, sokszor a közmunkásokkal azonosítják a szociális munkásokat: „És senki ilyen segítő foglalkozású ember nincs a településen? Nincs. Szociális munkás? Az van. A családsegítő? Nem, hát a tanácsnak van kirendelve, olyan, hogy vágják a füvet. Nem, az a közmunkás. Van családsegítő? Nincs, nincs." (Észak-magyarországi kistérség településén élő család)

A budapesti agglomerációhoz tartozó települések munkaerőpiaci helyzetét a válaszolók zöme pozitívan értékelte, jelenleg könnyű munkát találni, sok munkalehetőség áll az itt lakók rendelkezésére helyben is, de ennek ellenére sokan a budapesti munkavállalást preferálják és ingáznak. „Mind a ketten itt dolgozunk a városban, nem mondhatom, hogy nehéz. Most téma volt körülöttem, hogy szeretnének a kismamák visszamenni és föleg Pesten, de aki akar, talál itt is állást. Lehet találni, lehet mindig jobbat is.” (Budapesti agglomerációhoz tartozó településen élő család)

A hátrányos helyzetű kistérségben a munkaerőpiacon helyben nagyon kevés lehetőség áll rendelkezésre. A közeli kisvárosban akad munkalehetőség, de kevesebb, mint ahány potenciális munkavállaló jelenleg van a térségben. Sokan választják a rendkívül megterhelő ingázást Budapestre, ez hajnali indulást és késői érkezést jelent, ami mind a munkavállaló, mind a családja számára nagyon megterhelő. Az in- 


\section{TEMATIKUS TANULMÁNYOK - Társadalmi mobilitás és segítői tevékenység}

terjúk többségében megjelent a külföldi munkavállalás lehetősége, főleg a családok férfi tagjai számára. A megkérdezettek közül fontolgatják a külföldi munkavállalást többen is, mivel sok ismerősük dolgozik Svájcban, Németországban és Ausztriában. Visszatartó erő a döntésben a családtól való több hónapos távolmaradás, úgy vélik, hogy az anyagi haszonszerzés ezt nem kompenzálja, ezért inkább helyben próbálkoznak. „Hát a párom, amikor elküldték, mert becsukott az az üzlet, akkor gondolta, hogy kimegy külföldre, ugye, hogy itt volt 5 gyerek meg ugye mi is, és hat hónapig nem volt, ahonnan jött volna a fizetés, és már úgy volt, hogy kimegy külföldre, de mivel, hogy itt van 5 gyerek, nem akart volna, csak a pénz miatt." (Észak-magyarországi kistérség településén élő család)

Kulturális szolgáltatások elérhetőségével is elégedettek voltak az agglomeráció településein élők: a könyvtár, művelődési ház, közösségi programok elérhetőek és megfizethetőek. A hátrányos helyzetű kistérség településein viszont többnyire nincs semmilyen lehetőség.

\section{Összegzés}

A gyermekek mobilitási esélyeinek támogatása, illetve az ehhez kapcsolódó szolgáltatások elérhetősége és azok minősége alapvetően gyermekjóléti kérdés is. A gyermekvédelmi rendszerek magukba foglalják a konkrét gyermekjóléti és gyermekvédelmi ellátórendszer mellett a gyermekekkel foglalkozó egészségügyi és oktatási rendszereket, illetve a családokkal foglalkozó minden egyéb szolgáltatást is (Rácz 2016, Darvas 2018). A családok a társadalomba beágyazottan tudják megfelelően ellátni szocializációs és mobilizációs feladatukat, így társadalompolitikai szempontból nemcsak a szűken vett gyermekvédelem, hanem az egész társadalompolitikai működés és a kapcsolt szolgáltatások hatással vannak a gyermekek életére és integrációs, valamint mobilitási esélyeire. Az alábbi táblázatban a gyermekek mobilitási esélyeivel kapcsolatos kockázatok, illetve erőforrások szerepelnek, figyelembe véve a család helyzetét és a családok számára elérhető szolgáltatások körét. 


\section{TEMATIKUS TANULMÁNYOK - Társadalmi mobilitás és segítői tevékenység}

10. táblázat. Kockázatok és megelőző faktorok a gyermekek társadalmi mobilitási lehetőségeivel kapcsolatban

\begin{tabular}{|c|c|}
\hline Kockázatok & Megelőző faktorok \\
\hline $\begin{array}{l}\text { Szociökonómiai státusz } \\
\text { - szülő alacsony iskolai végzettsége } \\
\text { - munkanélküliség (tartós) } \\
\text { - munkaerőpiacon elfoglalt alacsony stá- } \\
\text { tuszú pozíció (segédmunka, betanított } \\
\text { - } \text { segédmunka) } \\
\text { - közmunkában való foglalkoztatottság }\end{array}$ & $\begin{array}{l}\text { - megfelelő jövedelmi helyzet } \\
\text { - magas színvonalú ellátások } \\
\text { - szülők magas iskolai végzettsége }\end{array}$ \\
\hline $\begin{array}{l}\text { Családi jellemzők } \\
\text { - anya fiatal életkora, tinédzserszülő } \\
\text { • családtagok, szülők szerhasználata } \\
\text { • családtagok, szülők pszichiátriai beteg- } \\
\text { sége } \\
\text { - családtagok, szülők bántalmazott, elha- } \\
\text { nyagolt gyermekkora } \\
\text { - magas gyermekszám a háztartásban, } \\
\text { családban }\end{array}$ & $\begin{array}{l}\text { - kétszülős háztartások } \\
\text { - állandó, stabil munkaviszony } \\
\text { - kompetens szülői attitűd }\end{array}$ \\
\hline $\begin{array}{l}\text { Oktatási rendszer helyzete } \\
\text { • iskolalátogatás hiánya } \\
\text { - megfelelő iskolai körülmények, módsze- } \\
\text { rek és szakemberek hiánya } \\
\text { - tankötelezettségi korhatár előtti iskola- } \\
\text { elhagyás }\end{array}$ & $\begin{array}{l}\text { - speciális iskolai támogatásokhoz, szol- } \\
\text { gáltatásokhoz való hozzáférés } \\
\text { - gyógypedagógus, pszichológus, egyéb } \\
\text { fejlesztő szakember elérhető } \\
\text { - iskolai szociális munka jelenléte }\end{array}$ \\
\hline $\begin{array}{l}\text { Egészségügyi helyzet } \\
\text { • megfelelő alap- és szakellátás hiánya } \\
\text { • megfelelő szakorvosi létszám hiánya } \\
\text { • gyógyszerhez való megfelelő hozzájutás } \\
\text { nehézsége } \\
\text { - szűrővizsgálatok hiánya }\end{array}$ & $\begin{array}{l}\text { - megfelelő szakemberek } \\
\text { - gyermekgyógyászat jó színvonalon } \\
\text { - rendszeres szűrések } \\
\text { - orvosi segédeszközökhöz (szemüveg, } \\
\text { fogszabályozás stb.) való hozzáférés } \\
\text { - prevenciós lehetőségek }\end{array}$ \\
\hline
\end{tabular}

Forrás: Saját szerkesztés

Az országos, megyei, kistérségi és helyi szintű intézmények felelőssége elsősorban a gyermekek védelmének biztosítása, ugyanakkor a társadalmi szereplők, civil és egyházi aktorok részvétele elengedhetetlen eleme egy hatékony gyermekvédelemnek. A jó minőségű gyermekvédelmi rendszerek multidiszciplinárisak és interszekcionálisak, azaz fontos, hogy folyamatos kapcsolatban legyenek, mind az oktatási, mind az egészségügyi rendszerekkel ahhoz, hogy a lehető legjobb ellátást tudják 


\section{TEMATIKUS TANULMÁNYOK - Társadalmi mobilitás és segítői tevékenység}

biztosítani minden gyermek, illetve leginkább a valamilyen szempontból hátrányos helyzetű vagy veszélyeztetettek számára. „A kutatások a gyermekek és fiatalok értelmes és őket megerősítő részvételének komplex feladatára hívják fel a figyelmet. Ehhez a szakembereknek a gyermeki jogokon kívül mozgósítaniuk kell a fejlödéslélektani és családdinamikai ismereteiket, tudásukat, valamint a gyermekekkel való hatékony kommunikáció készségeit kell alkalmazniuk." (Darvas 2018: 66) A gyermekcentrikus és családi fókuszú szemlélettel átitatott gyermekjóléti munkában a szülők bevonásával, az esetben érintett, társintézményekben dolgozó szakemberek mellett a gyermekekkel foglalkozó intézmények tágan értelmezett körével valósul meg az együttműködés (Wessels 2015, Rácz 2016, Darvas 2018). A családok támogatása mellett a humánökológiai rendszerelméletekben megjelenő mikro-, mezo- és makrorendszereknek a színvonala, működésének a minősége szignifikánsan befolyásolja a gyermekek szocializációját és jövőjét (Danis 2011). A területi különbségek ebben az esetben azt jelentik, hogy a gyermekek jövője, lehetőségeik és mobilizációja nagyban fog függeni attól, hogy hova születtek, mint ahogy ezt jelen kutatási eredményeink is megerősítik.

A kutatás kvantitatív és kvalitatív eredményei alapján elmondható, hogy a területi különbségek alapvetően meghatározzák a családok és gyermekeik mobilitási esélyeit. A budapesti agglomerációs településeken mind a munkaerőpiaci, mind az oktatási és az egészségügyi szolgáltatások elérhetőek, lehetőség van a választásra. Van fizetőképes kereslet, így megjelennek a magánpiaci szolgáltatók, illetve megfelelő a tömegközlekedés, az úthálózat és az infrastruktúra is, hogy a fővárosi ellátásokat és szolgáltatásokat is igénybe tudják venni, ha a lokális szolgáltatások nem lennének megfelelőek a családok számára. Ezzel ellentétben az észak-magyarországi térségben igen korlátozott számú szolgáltatás található meg helyben, azok minősége változó, a közeli városokat nehéz elérni, hiszen a tömegközlekedés nem megfelelő. Az egészségügyi, oktatási és kulturális vonatkozásban is a területi különbség nagyon erőteljesen jelenik meg. Ami meglepő, hogy a szociális ellátórendszer szinte láthatatlan mindkét vizsgálati területen, ha hallottak is a szociális intézményekről, ezek igénybevétele igen alacsony. Az a pár óra, amit egy-egy településen tölt a szociális szakember, nem elég ahhoz, hogy beépüljön az ott lakók életébe, nincs a gondolkodásukban, nem merül fel, hogy ezekhez az egyébként segítő szolgáltatásokhoz bizalommal fordulhatnának, ha esetleg nehézségük adódna a mindennapokban. Az a tény, hogy a szociális segítő szolgáltatásokból rekednek ki épp azok, akiknek segítségre van szükségük, sokatmondó abban a tekintetben, hogy az alulfinanszírozott, szakemberhiánnyal küzdő szociális ágazat milyen mértékben tud reagálni az adott településen vagy kistérségben élők problémáira.

A hatékony professzionális segítés kiindulópontja a segítő személyes jelenléte, a kliensek alapos és mély ismerete és ebből következően a kliensekkel való bizalmi kapcsolata. Alapvető probléma, hogy a vizsgált észak-magyarországi kistérségben nincs meg az alapja a hatékony és eredményes munkának. A különböző fejlesztő, 


\section{TEMATIKUS TANULMÁNYOK - Társadalmi mobilitás és segítői tevékenység}

jól-létet előmozdító szolgáltatások hiányában, a meglévő, igen korlátozott kapacitásokkal és így alacsony minőségben működő szolgáltatások az itt élő gyermekek mobilitási esélyeit korlátozzák. Ahhoz, hogy a jelenlegi helyzet érdemben változzon, az oktatási, egészségügyi, szociális és kulturális szolgáltatások minőségének kell jelentősen javulnia, amihez egyértelműen döntéshozói elköteleződésre is szükség van. A jövőbeli fejlesztési irányokat tekintve olyan gyermekjóléti és gyermekvédelmi politikára van szükség, amely a gyermekes családok élethelyzetét és komplex problémáit figyelembe veszi, képes összetett szolgáltatási csomaggal válaszolni az egyéni/családi igényekre. Alapvető, hogy ezek a szolgáltatások elérhetőek legyenek a területi különbségektől függetlenül és jó színvonalon működjenek (Rubeus Egyesület 2015). Fontos lenne a prevenciós megoldások bővítése a gyermekek fejlesztése érdekében és olyan célzott programok kidolgozása, melyek a szülői kompetenciákat fejlesztik. A közösségi erőforrások becsatornázása a segítői munkába alapvető fontosságú, mindez magában foglalja a civil és egyházi szereplők bevonását és az önkéntesek szerepének növelését is a gyermekes családokkal végzett szociális munkába (Wessels 2015, Rácz 2016, Darvas 2018).

\section{Irodalom}

A szociális munka globális definíciója (2014): Esély, 2014/6. 96-100. http://www. esely.org/kiadvanyok/2014_6/2014-6_3-1_szocialis-munka_globalis_definicioja.pdf (Utolsó letöltés: 2020. február 25.)

Czirják A. (2008): A gyermekvédelem története - Az 1997. évi gyermekvédelmi törvény megszületéséhez vezető út. http://rubeus.hu/wp-content/uploads/ 2013/ 09/22987_czirjakattila_gyvtortenete_ujabb.pdf (Utolsó letöltés: 2020. február 25.)

Danis I. - Kalmár M. (2011): A fejlődés természete és modellje. In: Danis I. - Farkas M. - Herczog M. - Szilvási L. (szerk.): A génektôl a társadalomig. Biztos Kezdet Kötetek 1. Budapest, NCSSZI 76-125. http://mek.oszk.hu/14800/14803/14803. pdf (Utolsó letöltés: 2020. február 25.)

Darvas Á. (2018): Komplex programok, szolgáltatások, szakmai munka és képzési, továbbképzési szükségletek. In: Rácz A. (szerk.): Szülői kompetenciafejlesztést célzó modellprogramok a gyermekjóléti szolgáltatások tárházában. Budapest, Rubeus Egyesület, 54-70.

http://rubeus.hu/wp-content/uploads/2015/08/szuloi_kompetenciafejlesztes_rubeus_20180919.pdf (Utolsó letöltés: 2020. február 25.)

Darvas Á. - Mózer P. - Tánczos É. (2016): Szolgáltatások átalakulóban - Pillanatkép 2016 tavaszáról. Párbeszéd, 2016/4, 1-26. http://parbeszed.lib.unideb.hu/ file/2/585a52d28e115/szerzo/DARVAS_Szolgaltatasok_atalakul\%EF\%BF\%BD. pdf (Utolsó letöltés: 2020. január 20.) 


\section{TEMATIKUS TANULMÁNYOK - Társadalmi mobilitás és segítői tevékenység}

Kopasz M. (2017): A családsegítő és gyermekjóléti szolgáltatás integrációjának és az ellátórendszer kétszintűvé történő átalakításának tapasztalatai. Budapest, TÁRKI http://old.tarki.hu/hu/news/2017/kitekint/20170425_csaladsegito.pdf (Utolsó letöltés: 2020. január 20.)

Messing V. - Molnár E. (2011a): Válaszok a pénztelenségre: szegény cigány és nem cigány családok megélhetési stratégiái. Esély, 2011/1, 53-80. http://esely.org/ kiadvanyok/2011_1/03messingmolnar.indd.pdf (Utolsó letöltés: 2020. január 20.)

Messing V. - Molnár E. (2011b): Bezáródó kapcsolati hálók: szegény roma háztartások kapcsolati jellemzői. Esély, 2011/5, 47-71. http://www.esely.org/kiadvanyok/2011_5/04molnar.indd.pdf (Utolsó letöltés: 2020. január 20.)

OECD (2009): The Welfare Effects of Social Mobility. https://www.oecd-ilibrary. org/docserver/221272634852.pdf?expires=1585572629\&id=id\&accname= guest\&checksum=1918B367EAD6D4A931EC81384F694D59 (Utolsó letöltés: 2020. január 20.)

OECD Report (2018): A Broken Social Elevator? How to Promote Social Mobility. http://www.oecd.org/social/broken-elevator-how-to-promote-social-mobility9789264301085-en.htm (Utolsó letöltés: 2020. január 20.)

Papp K. (2000): A gyermekjóléti szolgálatok főbb működési problémái. Család, Gyermek, Ifjúság, 2000/4, 50-63. http://www.csagyi.hu/kiadvanyok/folyoirat/ item/119-2000-4-szam (Utolsó letöltés: 2020. január 20.)

Pataki É. - Somorjai I. (2006): Szolgáltatásokkal a gyermekszegénység ellen. Szolgáltatásfejlesztési koncepció a gyermekszegénység elleni nemzeti programhoz. Budapest, MTA GYEP http://3sz.hu/sites/default/files/uploaded/szolgaltatasokkal_ a_gyermekszegenyseg_ellen_-_szolgaltatasfejlesztesi_koncepcio_a_gyermekszegenyseg_elleni_nemzeti_programhoz.pdf (Utolsó letöltés: 2020. február 20.)

Rácz A. (2016): A gyermekvédelem mint fragmentált társadalmi intézmény. Debrecen, Debreceni Egyetem Egyetemi Kiadó.

Rubeus Egyesület (2015): Gyermekjóléti szolgáltatások feladatellátásának értékelő elemzése. In: Rácz A. (szerk.): A gyermekjóléti szolgálatok feladatellátásának értékelő elemzése országos szinten. Műhelytanulmány. http://rubeus.hu/wp-content/uploads/2015/07/a-gyermekjoleti-szolgalatok-feladatellatasanak-ertekelo-elemzese-orszagos-szinten.pdf (Utolsó letöltés: 2020. január 20.)

Stryker, R. - Boddy, J. - Bragg, S. - Sims-Schouten, W. (2019): The Future of Childhood Studies. Children and Society, 33: 301-308. DOI:10.1111/chso.12345 https://onlinelibrary.wiley.com/doi/full/10.1111/chso.12345 (Utolsó letöltés: 2020. január 20.) 


\section{TEMATIKUS TANULMÁNYOK - Társadalmi mobilitás és segítői tevékenység}

Vajda Zs. (2000): A gyermekek évszázada után. Gyermekkor és iskola a huszonegyedik században. In: Pukánszky B. (szerk.): A gyermek évszázada. Budapest, Osiris Kiadó, 80-102. .https://osztalyfonok.hu/files/Vajda_Zsuzsa_Gyermekek.pdf (Utolsó letöltés: 2020. február 25.)

Váradi M. (2015): A túlélés és a társadalmi betagolódás között: Szegénység, kirekesztettség és kapcsolatrendszerek. In: Virág T. (szerk.): Törésvonalak: Szegénység és etnicitás vidéki terekben. Budapest, Argumentum Kiadó, 45-68.

http://www.regscience.hu:8080/xmlui/handle/11155/1010 (Utolsó letöltés: 2020. január 20.)

Wessells, M. G. (2015): Bottom-up approaches to strengthening child protection systems: Placing children, families, and communities at the center. Child Abuse \& Neglect, 43: 8-21. http://cpaor.net/sites/default/files/cp/Wessells-2015-JCAN. pdf (Utolsó letöltés: 2020. február 25.) 